\title{
MENINGKATKAN PERKEMBANGAN MOTORIK HALUS PADA ANAK MELALUI KEGIATAN MENGANYAM DENGAN MEDIA KERTAS LIPAT
}

\author{
Riyadlotus Sholichah \\ Sekolah Tinggi Agama Islam Daruttaqwa Gresik, Indonesia \\ Email: riyadlotussholichah@staidagresik.ac.id \\ Miftakhul Jannah \\ RA H. Achmad Ali Surabaya, Indonesia \\ Email: titata84@gmail.com
}

\begin{abstract}
Early childhood education is a form of education that focuses on laying the foundation towards physical growth and development, especially on the fine motor skills of children. The purpose of this research is to describe the effect of weaving on the fine motor skills of early childhood group B in RA H Achmad Ali. This research uses a descriptive quantitative approach. The location of this research is RA H. Achmad Ali, Surabaya City. The subjects of this study were the children of group B RA H. Achmad Ali, Surabaya City with a total of 20 children. Based on the research that has been done, it is found that before the teacher's action is taken, the average fine motor skills are $50.3 \%$ which is in the very poor category. After the action in the first cycle, the average result of fine motor skills was $66.56 \%$, which was in the poor category, this result increased compared to the pre-cycle results with an increase of $16.26 \%$. The assessment in cycle II showed that the average fine motoric ability was $85 \%$ which was in the good category, this result increased by $18.44 \%$ compared to the first cycle which was in the poor category.
\end{abstract}

Keyword: Fine Motor; Weaving; Folding Paper

\begin{abstract}
Abstark: Pendidikan anak usia dini merupakan bentuk penyelenggaraan pendidikan yang menitikberatkan pada peletakan dasar ke arah pertumbuhan dan perkembangan fisik terutama pada kemampuan motorik halus anak.Tujuan dari penelitian yang dilakukan ini adalah Untuk mendeskripsikan pengaruh kegiatan menganyam terhadap kemampuan motorik halus anak usia dini kelompok B di RA H. Achmad Ali Penelitian ini menggunakan jenis penelitian pendekatan deskriptif kuantitatif. Lokasi penelitian yang dilakukan adalah di RA H. Achmad Ali Kota Surabaya. Subjek penelitian ini adalah anak kelompok B RA H. Achmad Ali Kota Surabaya dengan jumlah 20 anak. Berdasarkan penelitian yang telah dilakukan diperoleh hasil bahwa sebelum dilakukan tindakan didapatkan rata kemampuan motorik halus adalah sebesar $50.3 \%$ yang masuk dalam kategori kurang sekali. Setelah dilakukan tindakan pada siklus I hasil rata-rata kemampuan motorik halus adalah sebesar 66.56\% yang masuk dalam kategori kurang, hasil tersebut meningkat dibandingkan dengan hasil pra-siklus dengan peningkatan sebesar 16.26\%. Penilaian pada siklus II didapatkan hasil rata-rata kemampuan motorik halus adalah sebesar $85 \%$ yang masuk dalam kategori baik, hasil ini meningkat sebesar $18.44 \%$ dibandingkan dengan siklus I yang masuk dalam kategori kurang.
\end{abstract}

Kata kunci: Motorik Halus; Menganyam; Kertas Lipat 


\section{Pendahuluan}

Pendidikan Anak Usia Dini adalah jenjang pendidikan sebelum anak menginjank jenjang pendidikan dasar. Pendidikan Anak Usia Dini merupakan suatu upaya pembinaan untuk anak usia 0 sampai dengan 6 tahun, dengan memberikan rangsangan pendidikan dengan tujuan membantu pertumbuhan dan perkembangan jasmani dan rohani anak supaya anak memiliki kesiapan mental dan fisik dalam memasuki pendidikan lebih lanjut yaitu di pendidikan dasar. Pendidikan anak usia dini merupakan bentuk penyelenggaraan pendidikan yang menitikberatkan pada peletakan dasar ke arah pertumbuhan dan perkembangan fisik (koordinasi motorik halus dan kasar), kecerdasan (daya pikir, daya cipta, kecerdasan emosi, kecerdasan spiritual), sosio emosional (sikap dan perilaku serta agama) bahasa dan komunikasi, sesuai dengan keunikan dan tahap-tahap perkembangan yang dilalui oleh anak usia dini. Undang-undang Republik Indonesia No. 20 Tahun 2003 tentang Sistem Pendidikan Nasional pasa 1 ayat 14 menyatakan bahwa pendidikan anak usia dini adalah suatu upaya pembinaan yang ditujukan kepada anak sejak lahir sampai dengan usia enam tahun, yang dilakukan melalui pemberian rangsangan pendidikan untuk membantu pertumbuhan dan perkembangan jasmani dan rohani agar anak memiliki kesiapan dalam memasuki pendidikan lebih lanjut. ${ }^{1}$

Taman Kanak-Kanak atau yang disingkat TK merupakan salah satu bentuk pendidikan prasekolah yang bertujuan membantu pertumbuhan anak sebelum memasuki pendidikan dasar dalam peraturan pemerintahan tentang pendidikan prasekolah dinyatakan dalam pasal 4 menyatakan pendidikan prasekolah adalah pendidikan untuk membantu pertumbuhan dan perkembangan jasmani dan rohani anak didik diluar lingkungan keluarga, sebelum memasuki pendidikan dasar yang diselenggarakan di jalur pendidikan prasekolah atau di jalur pendidikan luar sekolah (Agustin, 2017:4). ${ }^{2}$

Pendidkan TK di laksanakan dengan prinsip bermain sambil belajar, atau belajar seraya bermain. Sesuai dengan perkembangan, di harapkan adanya seorang pendidik yang kreatif dan inovatif agar anak bisa merasa senang, tenang, aman dan nyaman selama proses belajar mengajar. Berdasarkan standar kompetensi kurikulum TK tercantum bahwa tujuan pendidikan di TK adalah membantu mengembangkan berbagai potensi anak baik psikis dan fisik yang meliputi moral dan nilai-nilai agama, sosial emosional, kognitif, bahasa, fisik/motorik, kemandirian dan seni, untuk memasuki pendidikan dasar.

Salah satu aspek perkembangan anak usia dini di Taman Kanak-Kanak adalah perkembangan motorik. Artinya perkembangan keterampilan motorik sebagai perkembangan unsur kematangan dan pengendalian gerak tubuh. Bambang Sujiono dalam Nur mengemukakan bahwa perkembangan motorik adalah proses seseorang anak belajar untuk terampil menggerakkan anggota tubuh. Berdasarkan hal tersebut, anak belajar dari guru tentang beberapa pola gerakan yang dapat mereka lakukan yang dapat melatih ketangkasan, kecepatan, kekuatan, kelenturan, serta ketepatan koordinasi tangan dan mata. ${ }^{3}$

Kecerdasan motorik halus anak berbeda-beda. Hal kekuatan maupun ketepatannya. perbedaan ini juga dipengaruhi oleh pembawaan anak dan stimulasi yang didapatkannya. Lingkungan (orang tua) mempunyai pengaruh yang lebih besar dalam kecerdasan motorik halus anak. Lingkungan dapat meningkatkan ataupun menurunkan taraf kecerdasan anak, terutama pada masa-masa pertama kehidupannya.

\footnotetext{
${ }^{1}$ Undang-undang Republik Indonesia No. 20 Tahun 2003 tentang Sistem Pendidikan Nasional pasa 1 ayat 14

2 Agustin, Mubiar, Mengenali dan Mengembangkan Potensi Kecerdasan. Jamak. Anak Usia Taman Kanak-Kanak/ Raudhatul Athfal. (Bandung: Rizqipress, 2017), h. 4 .

${ }^{3}$ Hidayah, Nur.. Peningkatan Kemampuan Motorik Halus Melalui Kegiatan Menganyam Pada Anak Kelompok A2 Di TK PKK 30 Mulyorini Surobayan Argomulyo Sedayu Bantul. (Yogyakarta:UNY, 2013) , h. 2.
} 
Setiap anak mampu mencapai tahap perkembangan motorik halus yang optimal asal mendapatkan stimulasi tepat. Di setiap fase, anak membutuhkan rangsangan untuk mengembangkan kemampuan mental dan motorik halusnya. Semakin banyak yang dilihat dan didengar anak, semakin banyak yang ingin diketahuinya. Jika kurang mendapatkan rangsangan anak akan bosan. Tetapi bukan berarti anda boleh memaksa si kecil. Tekanan, persaingan, penghargaan, hukuman, atau rasa takut dapat mengganggu usaha dilakukan si kecil.

Mengembangkan kemampuan motorik, anak juga mengembangkan kemampuan mengamati, mengingat hasil pengamatan dan pengalamannya. Anak mengamati guru, anak lain atau dirinya saat bergerak. Ia kemudian mengingat gerakan motorik yang telah dilakukannya atau telah dilatihkan oleh gurunya agar dapat melakukan perbaikan dan penghalusan gerak. Anak juga harus memiliki keterampilan dasar terlebih dahulu sebelum ia mampu memadukannya dengan kegiatan motorik yang lebih kompleks.

Perkembangan motorik pada usia Taman Kanak-Kanak adalah belajar untuk bisa terampil menggerakkan anggota tubuh, baik motorik halus maupun motorik kasar. Gerakan motorik kasar adalah gerakan yang membutuhkan koordinasi sebagian besar bagian tubuh anak, sedangkan gerakan motorik halus adalah gerakan yang hanya melibatkan bagian-bagian tubuh tertentu saja dan dilakukan oleh otot-otot kecil seperti keterampilan menggunakan jari jemari tangan dan gerakan pergelangan tangan. Gerakan ini tidak terlalu membutuhkan tenaga, namun gerakan ini membutuhkan koordinasi mata dan tangan yang cermat (Bambang Sujiono dalam Nur 2015:2). ${ }^{4}$

Perkembangan motorik halus yang terlihat saat usia TK, antara lain adalah anak mulai dapat menyikat gigi, memakai sepatu sendiri, makan sendiri menggunakan sendok dan garpu, semakin baik gerakan motorik halus anak membuat anak dapat berkreasi seperti menggunting kertas dengan hasil guntingan yang lurus, menjahit, serta menganyam kertas. Menurut Sumantri dalam Nur mengemukakan program pengembangan keterampilan motorik anak usia dini seringkali terabaikan atau dilupakan oleh orangtua, pembimbing atau bahkan guru sendiri. Hal ini lebih dikarenakan mereka belum memahami bahwa program pengembangan keterampilan motorik menjadi bagian yang tidak terpisahkan dalam kehidupan anak usia dini.

\section{Kajian Teoritik}

Salah satu kemampuan yang dikembangkan di PAUD adalah perkembangan motorik halus. Perkembangan motorik halus berkaitan dengan perkembangan kemampuan dalam menggunakan jari-jari tangan untuk melakukan berbagai kegiatan. Misalnya, kemampuan memindahkan benda dari tangan, mencoret-coret, menyusun balok, menggunting, menulis dan sebagainya. Perkembangan motorik halus dipandang penting untuk dipelajari, karena baik secara langsung maupun tidak langsung akan mempengaruhi perilaku anak setiap hari. ${ }^{5}$

Keterampilan motorik adalah kemampuan seseorang untuk melakukan gerakan terkoordinasi menggunakan kombinasi berbagai tindakan otot. Keterampilan motorik halus cenderung dilakukan oleh otot-otot yang lebih kecil seperti yang di tangan dan menghasilkan tindakan seperti menulis dan menggambar. ${ }^{6}$ Menurut Muhibbin, motorik adalah segala keadaan yang menghasilkan rangsangan terhadap kegiatan organ fisik. Sedangkan menurut Zulkifli, motorik adalah segala sesuatu yang yang ada hubungnnya dengan gerakan-gerakan tubuh. Keterampilan

\footnotetext{
${ }^{4}$ Hidayah, Nur.. Peningkatan Kemampuan Motorik Halus Melalui Kegiatan Menganyam Pada Anak. Kelompok. A2 Di TK PKK 30 Mulyorini Surobayan Argomulyo Sedayu Bantul. (Yogyakarta:UNY, 2013) , h. 2.

${ }^{5}$ Wahyu Nanda Eka Saputra dan Indah Setianingrum, Perkembangan Motorik. Halus Anak Usia 3-4 Tabun, Jurnal Care Volume 03 Nomor 2 Januari 2016 PG PAUD IKIP PGRI Madiun.

${ }^{6}$ Samsudin, Pembelajaran Motorik Di Taman Kanak-Kanak, (Jakarta:Pranada Media Group, 2008), h. 8.
}

10 Riyadlotus, Miftakhul - Meningkatkan Perkembangan Motorik Halus pada Anak melalui Kegiatan Menganyam 
motorik merupakan faktor fisik yang dapat dikembangkan melalui belajar gerak. Motorik halus adalah gerakan yang dilakukan oleh bagian - bagian tubuh tertentu dan hanya melibatkan sebagian kecil otot tubuh. Gerakan ini tidak memerlukan tenaga, tapi perlu adanya koordinasi antara mata dan tangan. Gerak motorik halus merupakan hasil latihan dan belajar dengan memperhatikan kematangan gungsi organ motoriknya. ${ }^{7}$

Motorik halus merupakan suatu kegiatan yang menggunakan otot-otot kecil yang perlu adannya koordinasi antara mata dan jari- jari tangan, Dalam Depdiknas, Mengemukakan bahwa: "Motorik halus adalah gerakan yang melibatkan bagian-bagian tubuh tertentu yang dilakukan oleh otot-otot kecil serta memerlukan koordinasi yang cermat, seperti menggunting mengikuti garis, menulis, meremas, menggenggam, menggambar, menyusun balok, memasukan kelereng ke lubang, membuka dan menutup objek dengan mudah, menuangkan air ke dalam gelas tanpa berceceran, menggunakan kuas, krayon, dan spidol serta melipat." ${ }^{8}$

Salah satu perkembangan yang sedang berlangsung pada anak usia dini adalah perkembangan dalam motoriknya, menurut Sujiono, menjelaskan bahwa motorik adalah semua gerakan yang mungkin didapatkan oleh seluruh tubuh, sedangkan perkembangan motorik bisa disebut sebagai perkembangan dari unsur kematangan dan pengendalian gerak tubuh. Sejalan dengan pendapat tersebut menurut Hurlock, mengemukakan perkembangan motorik adalah perkembangan pengendalian gerakan jasmaniah melalui kegiatan pusat saraf, urat saraf, dan otot yang terkoordinasi.

Keterampilan motorik halus adalah kemampuan mengkoordinasi gerakan otot kecil dari anggota tubuh. Keterampilan motorik halus terutama melibatkan jari tangan, dan biasanya dengan koordinasi mata. Contoh keterampilan motorik halus adalah memegang, menulis, menggunting, dan lain sebagainya. Keterampilan motorik halus melibatkan kekuatan, kontrol motorik otot, dan deksteritas. Dalam Permen $58 \mathrm{hlm}$. 13, menyatakan bahwa: "Pola perkembangan atau tingkat pencapaian anak usia lima sampai enam tahun yaitu; menggambar sesuai gagasannya, meniru bentuk, melakukan eksplorasi dengan berbagai media dan kegiatan, menggunakan alat tulis dengan benar, menggunting dengan sesuai pola, menempel gambar dengan tepat, dan mengekspresikan diri melalui gerakan menggambar secara detail.”

Motorik halus merupakan keterampilan fisik yang melibatkan otot-otot ujung jari serta koordinasi mata dan tangan. Bagian tubuh lain yang terlibat dalam kegiatan motorik halus adalah pergelangan tangan, lengan, sampai pangkal lengan atas dan bagian sendi di bahu. Motorik halus dapat dilatih dan dikembangkan melalui kegiatan dan stimulasi secara rutin, seperti bermain puzzle, menyusun balok, memasukan benda ke dalam lubang sesuai bentuknya dan sebagainya. ${ }^{9}$

Gerakan motorik halus mempunyai peranan yang penting dalam pengembangan seni. Motorik halus adalah gerakan yang hanya melibatkan bagian-bagian tubuh tertentu yang dilakukan oleh otot-otot kecil. Seperti, gerakan jari dan pergelangan tangan. ${ }^{10}$ Menurut Moelichatoen, motorik adalah merupakan kegiatan yang menggunakan otot-otot halus pada jari dan tangan. Gerakan ini keterampilan bergerak. Sedangkan menurut Nur Salam, perkembangan motorik halus adalah kemampuan anak untuk mengamati sesuatu dan melakukan gerak yang melibatkan bagian-bagian tubuh tertentu dan otot-otot kecil, memerlukan koordinasi yang cermat serta tidak memerlukan banyak tenaga. ${ }^{11}$

\footnotetext{
7 Suyadi, Psikologi Belajar PAUD, (Yogyakarta: PEDAGOGIA, 2010), h. 69

8 Ajeng Nuazizah, Umar dan Susilowati, 2015, Op.Cit., h. 5

${ }^{9}$ Riany Ariesta, Alat Permainan Edukatif Lingkungan Sekitar Untuk, Anak Usia 0-1 Tahun, Bandung: PT. Sandiatra Sukses, 2011), h. 6.

${ }^{10}$ Yani Mulyani dan Juliska Gracinia, Mengembangkan kemampuan Dsar BALITA di Rumah Kemampuan Fisik, Seni, dan Manajemen Diri,(Jakarta:PT. Elex Media Komputindo, 2007), h. 2

11 Puri Aquarisnawati, dkk., Jurnal Fakultas Psikologi Universitas Hang Tuah Surabaya, 2011, Motorik Halus Pada Anak Usia Prasekolab Ditinjau Dari Bender Gestalt, INSAN Vol. 13, No. 03, h. 151
} 
Menurut Malina dan Bouchard (Martini Jamaris, 2006: 10) prinsip utama perkembangan motorik adalah kematangan, urutan, motivasi, pengalaman, dan latihan atau praktek. ${ }^{12}$ Salah satu prinsip perkembangan anak usia dini yang normal adalah terjadi suatu perubahan baik fisik maupun psikis sesuai dengan masa pertumbuhannya. Elizabeth B. Hurlock dalam Nur terdapat 5 prinsip perkembangan motorik anak adalah sebagai berikut: ${ }^{13}$

a. Perkembangan motorik bergantung pada kematangan otot dan syaraf. Perkembangan bentuk kegiatan motorik yang berbeda sejalan dengan perkembangan area pusat syaraf yang berbeda. Karena perkembangan system syaraf yang rendah, yang bertempat dalam urat syaraf tulang belakang. Pada waktu lahir berkembang lebih baik daripada pusat syaraf yang berada dalam otak, maka gerak reflek lebih baik dikembangkan dengan sengaja daripada berkembang sendiri.

b. Belajar keterampilan motorik tidak terjadi sebelum anak matang. Sebelum system syaraf dan otot berkembang dengan baik, upaya mengajarkan gerakan terampil pada anak akan sia-sia. Sama halnya bila upaya tersebut diprakasai oleh anak sendiri.

c. Perkembangan motorik mengikuti pola yang dapat diramalkan. Perkembangan motorik mengikuti hukum arah perkembangan, urutan perkembangan cephalocandal (kepala ke kaki) menunjukkan bahwa dalam masa awal bayi, terdapat gerakan yang lebih besar bagian kepala dari pada di bagian badan yang lain.

d. Menentukan norma perkembangan motorik. Kemungkinan perkembangan motorik mengikuti pola yang ditentukan berdasarkan umur rata-rata yang dimungkinkan menentukan norma untuk bentuk kegiatan motorik lainnya. Norma tersebut juga digunakan orang tua atau orang lain untuk mengikuti perkembangan anak.

e. Perbedaan individu dalam laju perkembangan motorik. Walaupun dalam aspek perkembangan mengikuti pola yang serupa tetapi dalam hal rincian pola tersebut ada perbedaan individu. Hal tersebut dapat mempengaruhi umur pada waktu perbedaan individu tersebut mencapai tahap berbeda.

Selain itu, Endang Rini Sukamti dalam Nur menjelaskan bahwa terdapat delapan hal penting dalam mempelajari keterampilan motorik diantaranya:

1) Kesiapan belajar, anak yang sudah memiliki kesiapan belajar akan lebih unggul dibanding anak yang belum memiliki kesiapan belajar.

2) Kesempatan belajar, banyak anak yang tidak berkesempatan untuk mempelajari keterampilan motorik karena hidup dalam lingkungan yang tidak menyediakan kesempatan belajar atau bisa saja orang tua merasa takut akan melukai anaknya.

3) Kesempatan berpraktek, anak harus diberi kesempatan untuk dapat berpraktek semaksimal mungkin dalam menguasai keterampilan meskipun demikian kualitas praktek jauh lebih penting dari kuantitasnya.

4) Modal yang baik, anak dalam mempelajari keterampilan motorik suka meniru suatu model memainkan peran yang penting, maka untuk dapat mempelajari keterampilan seharusnya mendapatkan model yang baik pula.

5) Bimbingan, untuk dapat meniru model yang betul maka membutuhkan bimbingan. Bimbingan dapat membantu anak dalam membetulkan suatu kesalahn sebelum kesalahan terlanjur melekat dan dipelajari.

\footnotetext{
12 Jumaris, Martini. Perkembangan dan Pengembangan Anak Usia Taman Kanak. Jakarta: PT Grasindo, 2006), h. 10.

${ }^{13}$ Hidayah Nur, Peningkatan Kemampuan Motorik Halus Melalui Kegiatan Menganyam Pada Anak Kelompok. A2 Di TK PKK 30 Mulyorini Surobayan Argomulyo Sedayu Bantul, (Yogyakarta:UNY, 2013).
} 
6) Motivasi, sumber motivasi umum adalah kepuasan pribadi yang diperoleh anak dari kelompok sebayanya, serta kompetensi terhadap perasaan kurang mampu dalam bidang lain. Motivasi bisa dating dari diri sendiri juga dari orang lain disekitarnya.

7) Setiap keterampilan motorik harus dipelajari secara individu, keterampilan gerak anak berbedabeda dan keterampilan mempunyai perbedaan tertentu, sehingga harus dipelajari secara individu, missal: memegang sendok.

8) Keterampialn sebaiknya dipelajari secara bertahap dan satu persatu sehingga tidak membosankan dan hasil maksimal.

Berdasarkan beberapa pendapat ahli maka dapat disimpulkan bahwa terdapat prinsip utama perkembangan motorik adalah kematangan, urutan, motivasi, pengalaman, dan latihan atau praktek. Dalam penelitian ini prinsip-prinsip tersebut sangat berpengaruh bagi perkembangan motorik anak sebab apabila salah satu prinsip tersebut tidak terpenuhi maka perkembangan motorik anak dapat terhambat.Menurut Sumanto (2005: 119) berkreasi senirupa bagi anak TK selain berupa kegiatan menggambar, melukis, mencetak, mozaik, montase, kolase, melipat, menggunting juga diberikan pengenalan keterampilan menganyam. Kegiatan menganyam dilakukan dengan cara menyusun bagian-bagian bahan (pita) anyaman membentuk suatu motif anyaman atau membentuk model anyaman. Melalui keterampilan menganyam diharapkan dapat mengembangkan kompetensi rasa seni, ketekunan, kesabaran, dan kecekatan anak TK sejalan dengan perkembangan rasa seninya. ${ }^{14}$

Sumanto menganyam adalah suatu kegiatan keterampilan yang bertujuan untuk menghasilkan aneka benda/barang pakai dan benda seni, yang dilakukan dengan cara saling menyusupkan atau menumpang tindihkan bagian - bagian pita anyaman secara bergantian. Lebih Lanjut Sumanto menjelaskan menganyam adalah kegiatan menjalinkan pita atau iratan yang disusun menurut arah dan motif tertentu.

Menganyam diartikan juga suatu teknik menjalinkan lungsi dengan pakan. Lungsi adalah pita/iratan anyaman yang letaknya tagak lurus terhadap si penganyam. Pakan adalah pita atau iratan yang di susupkan pada lungsi dan arahnya berlawanan atau melintang terhadap lungsi.Pada penelitian ini jenis anyaman yang diimplikasikan pada anak anak adalah anyaman sederhana yang disesuaikan dengan kemampuan dan tahapan kondisi anak sesuai usia.

\section{Metode}

Jenis penelitian ini adalah penelitian tindakan kelas dengan menggunakan pendekatan deskriptif kuantitati. Pada penelitian ini penulis mengumpulkan data dan mengamati secara saksama mengenai aspek-aspek tertentu yang berkaitan dengan peningkatan kemampuan motorik halus anak melalui kegiatan menganyam dengan media kertas, sehingga akan memperoleh data penelitian berupa data hasil observasi dan dokumentasi. Data-data yang diperoleh dari data hasil observasi kepada anak tentang kemampuan motorik halus kemudian diproses dan dianalisis lebih lanjut dengan dasar teori yang telah dipelajari sehingga memperoleh hasil rata-rata, sehingga dapat ditarik kesimpulan mengenai masalah yang diteliti. ${ }^{15}$

David Hopkins (2011:112) menjelasakan bahwa terdapat empat langkah pokok dalam Penelitian Tindakan Kelas dalam satu siklus yaitu perencanaan tindakan, pelaksanaan tindakan, tahap observasi dan tahap refleksi.

\footnotetext{
${ }^{14}$ Sumanto. Pengembangan Kreativitas Seni Rupa Anak TK. (Jakarta: Departemen Pendidikan Nasional, 2005), h. 119. ${ }^{15}$ Hopkins, David.Penelitian Tindakan Kelas.(Yogyakarta:Pustaka Pelajar, 2011).
} 


\section{Hasil Penelitian}

\section{Analisis data Kualitatif}

\section{Pra-Siklus}

Peneliti melakukan pengamatan mengenai kemampuan motorik halus anak. Berdasarkan pengamatan yang telah dilakukan sebelum dilakukan tindakan didapatkan hasil tentang kemampuan motorik halus anak yang dijelaskan dalam tabel sebagai berikut:

Tabel 1.Hasil Penilaian Kemampuan

Motorik Halus AnakPra-Siklus

\begin{tabular}{|c|l|c|}
\hline No & \multicolumn{1}{|c|}{ Nama } & Pra Siklus \\
\hline 1 & MuchammadHibriziHibatullah & 43.75 \\
\hline 2 & Muhammad RafliAqila & 62.5 \\
\hline 3 & Muhammad Iksan Putra A & 50 \\
\hline 4 & NailaAfikaZahroh & 56.25 \\
\hline 5 & Najwa Aulia Syifa & 62.5 \\
\hline 6 & NurinShifa Putri & 50 \\
\hline 7 & Nur AiniIzzayani & 37.5 \\
\hline 8 & Puan ArbaBiantoro & 50 \\
\hline 9 & Putri Mutiara AlianaRisqi & 50 \\
\hline 10 & QueensyahAlmairaJovita & 37.5 \\
\hline 11 & RahmaAyudya Putri & 50 \\
\hline 12 & Ramdhani Akbar Dwi Ariyanto & 50 \\
\hline 13 & Rabbani Muhammad Zaidan & 50 \\
\hline 14 & RaisyaAnindya Putri & 56.25 \\
\hline 15 & ShaufaZahiraAfrah & 43.75 \\
\hline 16 & SalsabilaFitrianaKusuma & 62.5 \\
\hline 17 & Tiara Ayu Larasati & 50 \\
\hline 18 & Maulana Ilham & 43.75 \\
\hline 19 & Muhammad Rizky Dwi P & 56.25 \\
\hline 20 & Muhammad Kelvin Aldiansyah & 43.75 \\
\hline & & 50.3 \\
\hline
\end{tabular}

Berdasarkan data tersebut dapat dijelaskan bahwa rata-rata kemampuan motorik halusanak didapatkan adalah sebesar 50.3 yang masuk dalam kategori kurang sekali, berdasarkan hal tersebut peneliti ingin melakukan tindakan berupa penerapan kegiatan menganyam untuk meningkatkan kemampuan motorik halus anak. Berdasarkan hasilobservasi perolehan persentase tentang kemampuan motorik halus anak, dapat dijelaskan rincian perolehan tingkat ketuntasananak dalam kemampuan motorik haluspada tabel berikut:

Tabel 2. Rekapitulasi Kategori Kemampuan Anak dalam Kemampuan motorik halusRefleksi Awal / Pra Siklus

\begin{tabular}{|c|c|c|c|}
\hline No & Kategori & Frekuensi & Persentase \\
\hline 1 & Tuntas & 0 & $0 \%$ \\
\hline 2 & Tidak Tuntas & 20 & $100 \%$ \\
\hline \multicolumn{2}{|c|}{ Jumlah } & 20 & $100 \%$ \\
\hline
\end{tabular}

Berdasarkan tabel tersebut dapat dijelaskan bahwa pada penilaian kemampuan motorik halus anakdidapatkan hasil bahwa tidak ada anak didik yang tuntas kriteria minimal yang telah ditentukan sebelumnya. 


\section{Siklus 1}

Pada pertemuan pertama tema yang diambil untuk menganyam adalah kebutuhanku dan kegiatan yang dilakukan adalah menganyam ketupat.Pada pertemuan kedua tema yang diambil adalah kebutuhanku dan kegiatan yang dilakukan adalah menganyam ikan.Penjelasan pelaksanaan tindakan siklus I dapat dilihat sebagai berikut:

1) Melaksanakan pembelajaran sesuai Rencana Kegiatan Harian yang telah disusun. Peneliti terlibat langsung dalam kegiatan dan merekam semua yang terjadi selama kegiatan yang berupa catatan pengamatan, foto/video serta hasil karya anak.

2) Melakukan proses menganyam sesuai dengan tema yang diberikan oleh peneliti.

3) Peneliti membantu siswa yang memiliki kemampuan kurang dalam menganyam bentuk.

4) Melaksanakan evaluasi belajar yang telah dilaksanakan anak selama program kegiatan dan menganalisis perkembangan yang terjadi pada anak.

\section{Observasi Siklus I}

Observasi dilakukan oleh peneliti sejak awal penyusunan, pelaksanaan pembelajaran hingga evaluasi dengan penerapan kegiatan menganyam anak. Berdasarkan hasil observasi diperoleh beberapa catatan serta hasil penilaian terhadap kemampuan anak dalam kemampuan motorik halussebagai berikut:

Tabel 3.Hasil Penilaian Kemampuan

Kemampuan Motorik Halus Anak Siklus I

\begin{tabular}{|l|l|l|}
\hline No & Nama & Siklus I \\
\hline 1 & MuchammadHibriziHibatullah & 56.25 \\
\hline 2 & Muhammad RafliAqila & 75 \\
\hline 3 & Muhammad Iksan Putra A & 68.75 \\
\hline 4 & NailaAfikaZahroh & 62.5 \\
\hline 5 & Najwa Aulia Syifa & 75 \\
\hline 6 & NurinShifa Putri & 62.5 \\
\hline 7 & Nur Ainilzzayani & 50 \\
\hline 8 & Puan ArbaBiantoro & 62.5 \\
\hline 9 & Putri Mutiara AlianaRisqi & 75 \\
\hline 10 & QueensyahAlmairaJovita & 56.25 \\
\hline 11 & RahmaAyudya Putri & 62.5 \\
\hline 12 & Ramdhani Akbar Dwi Ariyanto & 62.5 \\
\hline 13 & Rabbani Muhammad Zaidan & 75 \\
\hline 14 & RaisyaAnindya Putri & 68.75 \\
\hline 15 & ShaufaZahiraAfrah & 62.5 \\
\hline 16 & SalsabilaFitrianaKusuma & 75 \\
\hline 17 & Tiara Ayu Larasati & 75 \\
\hline 18 & Maulana Ilham & 75 \\
\hline 19 & Muhammad Rizky Dwi P & 75 \\
\hline 20 & Muhammad Kelvin Aldiansyah & 56.25 \\
\hline Rata-Rata & & 66.56 \\
\hline
\end{tabular}

Berdasarkan data tersebut diatas dapat dijelaskan bahwa rata-rata klasikal anak dalam kemampuan motorik halus adalah sebesar 66.56 yang masuk dalam kategori kurang, kategori ini meningkat daripada pelaksanaan pra siklus dengan kategori kurang sekali. Berdasarkan hal tersebut dapat dijelaskan bahwa penerapan kegiatan menganyam dalam meningkatkan kemampuan motorik halus anak berhasil walaupun belum mencapai ketentuan rata-rata klasikal minimal yaitu sebesar 70. Berdasarkan hasil perolehan persentase tentang kemampuan 
motorik halus anak, dapat dijelaskan rincian perolehan tingkat ketuntasananak dalam kemampuan motorik haluspada tabel berikut:

Tabel 4.Rekapitulasi Rekapitulasi Kategori Kemampuan Anak dalam Kemampuan Motorik Halus Siklus I

\begin{tabular}{|c|c|c|c|}
\hline No & Kategori & Frekuensi & Persentase \\
\hline 1 & Tuntas & 8 & $40 \%$ \\
\hline 2 & Tidak Tuntas & 12 & $60 \%$ \\
\hline \multicolumn{2}{|c|}{ Jumlah } & 20 & $100 \%$ \\
\hline
\end{tabular}

Berdasarkan tabel tersebut dapat dijelaskan bahwa pada penilaian kemampuan motorik halus anakdidapathan hasil bahwa sebanyak 8 anak atau sebesar 40\% telahtuntas kriteria minimal yang telah ditentukan sebelumnya, sedangkan sebanyak 12 anak atau sebesar $60 \%$ masih belum memenuhi kriteria minimal yang ditentukan. Berdasarkan hal tersebut, penelitian pada siklus I masih belum sempurna karena ketuntasan minimal adalah sebanyak 16 anak yang tuntas atau sebesar $80 \%$ anak yang menjadi subjek penelitian tuntas dalam mengembangkan kemampuan motorik halus.

\section{Siklus 2}

Pada pertemuan pertama tema yang diambil untuk menganyam adalah rekreasi dan kegiatan yang dilakukan adalah menganyam gunung.Pada pertemuan kedua tema yang diambil adalah rekreasi dan kegiatan yang dilakukan adalah menganyam tikar. Penjelasan pelaksanaan tindakan siklus II dapat dilihat sebagai berikut:

1) Melaksanakan pembelajaran sesuai Rencana Kegiatan Harian yang telah disusun. Peneliti terlibat langsung dalam kegiatan dan merekam semua yang terjadi selama kegiatan yang berupa catatan pengamatan, foto/video serta hasil karya anak.

2) Melakukan proses menganyam sesuai dengan tema yang diberikan oleh peneliti.

3) Peneliti membantu siswa yang memiliki kemampuan kurang dalam menganyam bentuk.

4) Melaksanakan evaluasi belajar yang telah dilaksanakan anak selama program kegiatan dan menganalisis perkembangan yang terjadi pada anak.

\section{a. Observasi Siklus II}

Tahap observasi dilakukan oleh peneliti sejak awal penyusunan, pelaksanaan pembelajaran hingga evaluasi dengan penerapan kegiatan menganyamterhadap anak didik. Berdasarkan hasil observasi diperoleh beberapa catatan serta hasil penilaian terhadap kemampuan anak dalam menganyam untuk kemampuan motorik halusnya adalah sebagai berikut:

Tabel 5.Hasil Penilaian Kemampuan Kemampuan motorik halus Anak Siklus II

\begin{tabular}{|c|l|c|}
\hline No & \multicolumn{1}{|c|}{ Nama } & Siklus II \\
\hline 1 & MuchammadHibriziHibatullah & 75 \\
\hline 2 & Muhammad RafliAqila & 87.5 \\
\hline 3 & Muhammad Iksan Putra A & 87.5 \\
\hline 4 & NailaAfikaZahroh & 81.25 \\
\hline 5 & Najwa Aulia Syifa & 87.5 \\
\hline 6 & NurinShifa Putri & 87.5 \\
\hline 7 & Nur AiniIzzayani & 68.75 \\
\hline 8 & Puan ArbaBiantoro & 81.25 \\
\hline 9 & Putri Mutiara AlianaRisqi & 87.5 \\
\hline 10 & QueensyahAlmairaJovita & 68.75 \\
\hline
\end{tabular}




\begin{tabular}{|c|l|c|}
\hline 11 & RahmaAyudya Putri & 87.5 \\
\hline 12 & Ramdhani Akbar Dwi Ariyanto & 87.5 \\
\hline 13 & Rabbani Muhammad Zaidan & 93.75 \\
\hline 14 & RaisyaAnindya Putri & 87.5 \\
\hline 15 & ShaufaZahiraAfrah & 87.5 \\
\hline 16 & SalsabilaFitrianaKusuma & 93.75 \\
\hline 17 & Tiara Ayu Larasati & 87.5 \\
\hline 18 & Maulana Ilham & 87.5 \\
\hline 19 & Muhammad Rizky Dwi P & 93.75 \\
\hline 20 & Muhammad Kelvin Aldiansyah & 81.25 \\
\hline \multicolumn{2}{|c}{ Rata-Rata } & 85 \\
\hline
\end{tabular}

Berdasarkan data tersebut diatas dapat dijelaskan bahwa rata-rata klasikal anak dalam kemampuan motorik halus adalah sebesar 85 yang masuk dalam kategori baik, kategori ini meningkat daripada pelaksanaan siklus I dengan kategori kurang. Berdasarkan hal tersebut dapat dijelaskan bahwa penerapan kegiatan menganyam dalam meningkatkan kemampuan motorik halus anak berhasil mencapai ketentuan rata-rata klasikal minimal yaitu sebesar 70 . Berdasarkan hasil perolehan persentase tentang kemampuan motorik halus anak, dapat dijelaskan rincian perolehan tingkat ketuntasananak dalam kemampuan motorik haluspada tabel berikut:

Tabel 6.Rekapitulasi Rekapitulasi Kategori Kemampuan Anak dalam Kemampuan motorik halusSiklus II

\begin{tabular}{|c|c|c|c|}
\hline No & Kategori & Frekuensi & Persentase \\
\hline 1 & Tuntas & 18 & $90 \%$ \\
\hline 2 & Tidak Tuntas & 2 & $10 \%$ \\
\hline \multicolumn{2}{|c|}{ Jumlah } & 20 & $100 \%$ \\
\hline
\end{tabular}

Berdasarkan tabel tersebut dapat dijelaskan bahwa pada penilaian kemampuan motorik halus anakdidapathan hasil bahwasebanyak 18anak didikatau sebesar $90 \%$ yang tuntas kriteria minimal yang telah ditentukan sebelumnya, sedangkan sebanyak 2 anak didik atau sebesar 10\% masih belum memenuhi kriteria minimal yang ditentukan. Berdasarkan hal tersebut, penelitian pada siklus II sudah memenuhi ketuntasan minimal yaitu sebanyak 16 anak yang tuntas atau sebesar $80 \%$ anak yang menjadi subjek penelitian tuntas dalam kemampuan motorik halus.

\section{Analisis Data Kuantitatif}

Berdasarkan penelitian yang telah dilakukan sebelumnya dengan melakukan observasi, diperoleh hasil penelitian pada pra-siklus, siklus I, siklus II dapat dijelaskan dalam tabel berikut:

Tabel 7. Rekapitulasi Kemampuan Anak dalam Kemampuan motorik halus Pra-Siklus, Siklus I dan Siklus II

\begin{tabular}{|c|c|c|c|}
\hline \multicolumn{3}{|c|}{ Jumlah skor $(\%)$} & \multirow{2}{*}{ Keterangan } \\
\hline Pra-Siklus & Siklus I & Siklus II & \\
\hline $\mathbf{5 0 . 3} \%$ & $\mathbf{6 6 . 5 6} \%$ & $\mathbf{8 5} \%$ & Meningkat \\
\hline
\end{tabular}

Berdasarkan tabel tersebut dapat dijelaskan bahwa hasil kemampuan motorik halus anaksebelum dilakukan penerapan kegiatan menganyamoleh penelitidan setelah dilakukan penerapan kegiatan menganyamoleh peneliti pada siklus I dan siklus II terlihat mengalami peningkatan yang signifikan.Pada pra-siklus rata-rata kemampuan motorik halusadalah sebesar 50.3\% yang masuk dalam kategori kurang sekali. Penilaian pada siklus I setelah diterapkannya kegiatan menganyam oleh peneliti didapatkan hasil rata-rata kemampuan motorik halusadalah sebesar $66.56 \%$ yang masuk dalam kategori kurang, hasil tersebut meningkat dibandingkan 
dengan hasil pra-siklus dengan peningkatan sebesar 16.26\%. Penilaian pada siklus II didapatkan hasil rata-rata kemampuan motorik halusadalah sebesar 85\% yang masuk dalam kategori baik, hasil ini meningkat sebesar $18.44 \%$ dibandingkan dengan siklus I yang masuk dalam kategori kurang.

Sehingga dinilai tindakan yang dilakukan pada siklus II sudah berhasil memenuhi kriteria keberhasilan yang telah ditentukan, untuk itu tidak perlu adanya perlakukan tindakan pada siklus berikutnya.

\section{Kesimpulan}

Berdasarkan hasil penelitian yang dilakukan didapatkan kesimpulan bahwa dengan adanya penerapan kegiatan menganyam menggunakan media kertas yang diterapkan oleh guru kepada anak dapat meningkatkan kemampuan motorik halusnya. Hal tersebut dapat dilihat melalui hasil observasi yang dilakukan oleh peneliti. Sebelum diterapkan kegiatan menganyam, anak cenderung pasif dan sulit untuk menggerakkan tangannya terutama saat melakukan kegiatan di kelas. Setelah diterapkannya kegiatan menganyam pada anak ternyata kemampuan motorik halusnya meningkat. Pada pra siklus atau observasi sebelum diterapkannya kegiatan menganyam, hasil rata-rata kemampuan motorik halus anak adalah sebesar 50.3\% masuk kategori kurang sekali. Setelah diterapkannya kegiatan menganyam pada anak kemampuan anak meningkat yang ditandai dengan hasil rata-rata observasi mengenai kemampuan motorik halus anak menjadi kurang $66.56 \%$ yang masuk dalam kategori kurang, hasil tersebut meningkat dibandingkan dengan hasil pra-siklus dengan peningkatan sebesar $16.26 \%$. Kemudian setelah melakukan perbaikan pada siklus II, hasil observasi kemampuan motorik halus anak meningkat menjadi $85 \%$ yang masuk dalam kategori baik, hasil ini meningkat sebesar $18.44 \%$ dibandingkan dengan siklus I yang masuk dalam kategori kurang. Oleha karena itu dapat disimpulkan bahwa penerapan kegiatan menganyam dengan menggunakan media kertas dapat meningkatkan kemampuan motorik halus anak. 


\section{Daftar Pustaka}

Abu Bakar, hasnan. 2009. Perkembangan Ilmu Hadist. PTS ISLAMIKA:Selangor Rahman.

Agustin, Mubiar. 2017. Mengenali dan Mengembangkan Potensi Kecerdasan. Jamak Anak Usia Taman Kanak-kanak/ RaudhatulAthfal. Bandung: Rizqipress.

Ajeng Nuazizah, Umar dan Susilowati, 2015, Jurnal Guru Pendidikan Anak Usia Dini, Mengembangkan Motorik. Halus Anak melalui Pemanfaatan Media Daur Ulang, hlm. 5

Ajeng Nuazizah, Umar dan Susilowati, 2015, Op.Cit., h. 5

Arikunto, S. 2010. Prosedur Penelitian: Suatu Pendekatan Praktik. Jakarta: Rineka Cipta.

Hidayah, Nur. 2013. Peningkatan Kemampuan Motorik Halus Melalui Kegiatan Menganyam Pada Anak Kelompok A2 Di TK PKK 30 MulyoriniSurobayanArgomulyoSedayu Bantul.Yogyakarta:UNY.

Hopkins, David.2011.Penelitian Tindakan Kelas.Yogyakarta:Pustaka Pelajar.

John W. Santrock. Perkembangan Anak. Alih Bahasa :MeitasariTjandrasa dan MuchichabZarkasib. (Jakarta: Erlangga, 2007), h. 216.

Jumaris, Martini. Perkembangan dan Pengembangan Anak Usia Taman Kanak. Jakarta: PT Grasindo, 2006), h. 10.

Mulyati, Atik. 2014. Peningkatan Keterampilan Motorik Halus Melalui Origami Pada Anak Kelompok A TK KusumaBaciroGondokusuman Yogyakarta.Yogyakarta:UNY.

Nuraeni, Oktavia. 2014. Peningkatan Keterampilan Motorik Halus Melalui Kegiatan Menganyam dengan Kertas Pada Anak Kelompok B TK KKLKMD Sedyo Rukun Bambanglipuro Bantul.Yogyakarta:UNY.

Pamadhi, Hajar, dkk. Seni Keterampilan Anak. (Jakarta: Universitas Terbuka, 2008).

Puri Aquarisnawati, dkk., Jurnal Fakultas Psikologi Universitas Hang Tuah Surabaya, 2011, Motorik Halus Pada Anak Usia Prasekolah Ditinjan Dari Bender Gestalt, INSAN Vol. 13, No. 03, h. 151

RianyAriesta, Alat Permainan Edukatif Lingkungan Sekitar Untuk, Anak Usia 0-1 Tabun, Bandung: PT. Sandiatra Sukses, 2011), h. 6,

Samsudin, Pembelajaran Motorik Di Taman Kanak-Kanak, (Jakarta:Pranada Media Group, 2008), h. 8.

Sujiono, Bambang. Pengembangan Metode Fisik. Jakarta: Universitas Terbuka, 2005), h. 14.

Sumanto.Pengembangan Kreativitas Seni Rupa Anak TK. (Jakarta: Departemen Pendidikan Nasional, 2005), h. 119.

Sumantri.Model Pengembangan Keterampilan Motorik Anak Usia Dini. (Jakarta: Departemen Pendidikan Nasional, 2005).

Susilowati.Upaya Meningkatkan Kemampuan Motorik Halus Anak Usia Dini Menggunakan Kirigami Pada Anak. Kelompok B2 TK ABA Gendol Tempel Sleman.(Skripsi. UNY, 2012).

Suyadi, Psikologi Belajar PAUD, (Yogyakarta: PEDAGOGIA, 2010), h. 69

Undang-undang Republik Indonesia No. 20 Tahun 2003 tentang Sistem Pendidikan Nasional

Wahyu Nanda Eka Saputra dan Indah Setianingrum, Perkembangan Motorik Halus Anak Usia 3-4 Tahun, Jurnal Care Volume 03 Nomor 2 Januari 2016 PG PAUD IKIP PGRI Madiun. 
Yani Mulyani dan JuliskaGracinia, Mengembangkan kemampuan Dsar BALITA di Rumah Kemampuan Fisik, Seni, dan Manajemen Diri,(Jakarta:PT. Elex Media Komputindo, 2007), h. 2

Yudha, Rudyanto. Pembelajaraan Kooperatif untuk Meningkatkan Keterampilan Anak. TK. (Jakarta: Departemen Pendidikan Nasional, 2005), h. 115. 